\title{
Traduções de John Keats
}

\author{
Alberto Marsicano \& John Milton
}

Há poucas traduções de Keats no Brasil, e isso despertou nosso interesse em traduzi-lo e dar maior destaque a este grande poeta da língua inglesa, que, se não tivesse morrido de tuberculose em 1821 aos 25 anos, teria sido até mais famoso do que o próprio Shakespeare.

Trabalhamos a quatro mãos, eu fazendo uma traduçāo literal, que Marsicano melhorava e anotava. Depois das sessōes em que traduzimos dois ou três poemas curtos ou várias estrofes de um poema mais longo, Marsicano aprimorava o poema sozinho. Por fim, fizemos mais correçōes conjuntamente.

Na primeira sessão decidimos que não seria possível usar rimas na tradução, a obrigação de rimar nos colocaria uma camisa de força. Todo verso seria traduzido em torno daquela palavra que teria que rimar, empobrecendo a qualidade da linguagem em geral. Assim, decidimos nos concentrar mais na qualidade da linguagem em geral, tentando nos aproximar da grande sonoridade da poesia de Keats. Julgamos ser essa a forma mais leal de traduzir esse grande poeta inglês.

As seguintes traduçōes fazem parte de Traduçōes de John Keats, a ser publicado pela Editora lluminuras em 1998.

John Milton 


\title{
Escrito no Cimo do Ben Nevis
}

Leia-me a prece, Musa, e em voz alta No cimo do Nevis, velado na névoa! Miro os abismos, e uma mortalha De vapor os encobre - tal qual O conhecimento do homem sobre o inferno; ergo os olhos

E vejo a soturna neblina - tal qual

O conhecimento do homem sobre o cév; a neblina se esparge

Sobre a terra lá embaixo, - tal qual,

Täo vago quanto o conhecimento do homem sobre si mesmo!

Aqui estão as pedras ásperas sob meus pés, -

E tudo que sei, eu, um pobre e tolo elfo, É que piso sobre elas, - tudo que meus olhos vêem

É neblina e rochas, não apenas nestas alturas

Mas no mundo do pensamento e poder mental.

\section{Written upon the Top of Ben Nevis}

\author{
Read me a lesson, Muse, and speak it loud \\ Upon the top of Nevis, blind in Mist! \\ I look into its chasms, and a shroud \\ Vaporous doth hide them, - just so much I wist \\ Mankind do know of hell; I look o'erhead, \\ And there is sullen mist, - even so much \\ Mankind do know of heaven; mist is spread \\ Before the earth, beneath me, - even such, \\ Even so vague is man's sight of himself! \\ Here are the craggy stones beneath my feet, - . \\ This much I know that, a poor witless elf, \\ I tread on them, - that all my eye doth meet \\ Is mist and crag, not only on this height, \\ But in the world of thought and mental might! \\ De Selected Poems and Letters, ed. Douglas Bush, Houghton Mifflin, \\ Boston, 1959, p. 160
}




\section{A Véspera de Santa Agnes, Estrofe XXIV}

A janela esguia de três arcos, Com guirlandas e imagens incrustadas

De frutas, flores e touças de relvas,

E vitrais quais diamantes ornados, Incontáveis tintas em matizes esplêndidos, Asas adamascadas das mariposas pintadas;

Através de mil heráldicas,

Santos crespulares, e escuros brasōes, Um escudo rubesceu ao sangue de reis e rainhas.

\section{The Eve of St. Agnes, Stanza XXIV}

A casement high and triple-arched there was, All garlanded with carven imag'ries

Of fruits and flowers, and bunches of knot-grass,

And diamonded with panes of quaint device, Innumerable of stains and splendid dyes,

As in the tiger moth's deep-damasked wings;

And in the midst, 'mong thousand heraldries,

And twilight saints, and dim emblazonings,

A shielded scutcheon blushed with blood of queens and kings.

De The Selected Poetry of John Keats, ed. Paul de Man. Signet, New York, 1966, p. 237 
MARSICANO, A. \& MILTON, J. Traduçōes de John Keats.

\section{No Mar}

Ele sustém eternos murmúrios nas

Praias desoladas, e com suas soberbas cristas

Inunda vinte mil cavernas, até que o sortilégio

De Hecate as deixe com seu velho e assombroso som.

Muitas vezes se encontra tão tranqüilo,

Que até a menor das conchas permanece dias imóvel

Desde o desenlace dos ventos celestiais.

Vós, cujos olhos se enchem de tormento e tédio,

Regozijai-os com a imensidão do mar;

Vós, cujos ouvidos estão atordoados pelo rude ruído,

Ou enfastiados pela música melosa -

Sentai-vos na boca de uma velha caverna, e meditai

Até que escuteis, como se cantassem, as ninfas do mar!

\section{On the Sea}

It keeps eternal whisperings around

Desolate shores, and with its mighty swell

Gluts twice ten thousand caverns, till the spell

Of Hecate leaves them their old shadowy sound.

Often 'tis in such gentle temper found,

That scarcely will the very smallest shell

Be moved for days from where it sometime fell,

When last the winds of heaven were unbound.

Oh ye! whose ears are dinned with uproar rude,

Or fed too much with cloying melody -

Sit ye near some old cavern's mouth, and brood

Until ye start, as if the sea nymphs quired!

De The Selected Poetry of John Keats, ed. Paul de Man. Signet, New York, 1966, p. 90-91 